\title{
Clinical and experimental results of removing the large intestine soon after birth
}

\author{
A. W. WILKINSON and R. A. MCCANCE \\ From the Institute of Child Health and The Hospital for Sick Children, London; and \\ Sidney Sussex College, Cambridge
}

Wilkinson, A. W., and McCance, R. A. (1973). Archives of Disease in Childhood, 48, 121. Clinical and experimental results of removing the large intestine soon after birth. A boy from whom the distal $7 \mathrm{~cm}$ of the ileum, ileocaecal valve, caecum, and the ascending, transverse, and most of the pelvic parts of the colon had been removed in the neonatal period, was reinvestigated when he was $9 \frac{1}{2}$ years old. He had developed normally and was constipated.

An almost identical operation was carried out on 9 piglets when they were 10 days old. After early difficulties with diarrhoea, 5 of these animals became functionally mature even if rather small. As adults, the intestinal tracts behaved normally. No evidence of hypertrophy was found in any part of the small intestine or rectum.

Gangrene of the bowel is a rare but recognized complication of exchange transfusion soon after birth (McCandless, 1971, 1972; Hey, Ellis, and Walker, 1972). Complete removal of the caecum and colon for this cause is most uncommon in the neonatal period. The present paper describes the metabolic investigation of a neonate soon after such a resection and subsequently nearly 10 years later, and an experimental study of the results of a similar operation in newborn pigs. The size of piglets makes them satisfactory models for neonatal surgery and they have been used also by Rickham (1967), as have larger pigs by Brown (1938).

\section{Patient and experimental animals}

The boy was born at term after a normal pregnancy and weighed $2.92 \mathrm{~kg}$. On the third day of life his serum bilirubin was $29 \mathrm{mg} / 100 \mathrm{ml}$ and an exchange transfusion was performed. 24 hours later his abdomen was distended with gas but was not tender, and fluid levels were not seen in the upright $x$-ray. On the fifth day an indefinite tender mass was felt in the right lower quadrant of the abdomen and in the right flank. At laparotomy patches of gangrene were found in the caecum, and the ascending, transverse, descending, and pelvic parts of the colon. The distal $7 \mathrm{~cm}$ of the ileum and the caecum and colon to the terminal part of the pelvic colon were resected, and the end of the ileum was anastomosed to the stump of the distal pelvic colon. No intravenous fluid was given, but 36 hours after operation he was given $5 \mathrm{ml}$ of $5 \%$ glucose hourly by mouth for 6 hours; $25 \%$ breast milk in water was

Received 12 June 1972. then given, and was gradually increased in strength and quantity. His progress was very satisfactory and a balance study was made between the 12th and 15th days of life.

When the boy was 26 days old he brought up a large vomit of thick stale curd and some bile-stained fluid, and did so repeatedly during the following night but without great abdominal distension. An upright $x$-ray revealed multiple 'levels', and at laparotomy the cause was found to be adhesions which were divided; his progress was satisfactory till he was discharged. A brief report of the boy at this stage was given by Wilkinson, Hughes, and Toms (1963).

He was reinvestigated when he was 9 years and 6 months old. His height was $135.5 \mathrm{~cm}$ and his weight $27 \cdot 2 \mathrm{~kg}$. He was, therefore, about the $57 \mathrm{th}$ centile for height and the 35th for weight (Tanner, Whitehouse, and Takaishi, 1966). He had a good appetite and ate well, and he looked healthy and well nourished, but he was extremely constipated except when taking laxatives. Before he was admitted his bowels had been moving two or three times a day in consequence. He had some enlarged glands in his neck, axillae, and groins, but his Heaf test was negative at a dilution of 1 in 10,000, and no cause for their enlargement was found. Nothing abnormal was found in his abdomen.

The laxatives were stopped in preparation for the 5-day balance studies and he at once became very constipated. The marker taken at the beginning of the balance period was not passed for 7 days and then only after he had been given a 'Dulcolax' suppository. The marker taken at the conclusion of the balance was also not passed till a second suppository was given.

Thirteen piglets, derived from three litters were used. Two of them, females, acted as controls and, 
apart from not being subjected to operation, were treated and fed throughout in exactly the same way as the experimental ones. Operations were performed 10 to 14 days after delivery under general anaesthesia using ethyl ether administered with an open mask. The animals were taken from the mother, starved for a few hours before the operation, and put back to the sow on the following day. This was more successful than weaning them either before or immediately after the operation which had been the practice in an earlier series of experiments (McCance and Wilkinson, 1967), but in other respects their subsequent feeding and handling were the same.

A midline incision was made from the xiphoid process towards the umbilicus, then lateral to it for another inch or so. All the layers of the abdominal wall were divided in the line of the skin incision. The umbilical vein was ligated and divided. The colon was lifted out and the ileum divided about $10 \mathrm{~cm}$ above the ileocaecal valve where the ileal and ileocolic vascular territories join. The mesocolon was then divided between artery forceps and the whole of the colon lifted out of the abdomen.

In the first two pigs the colon was divided where it joins the rectum, but, because of technical difficulties in the dissection of the distal stump of the pelvic colon, it seems better to simplify the operation even if it meant leaving a little more of the large intestine in situ. In the other 9 pigs the pelvic colon was divided just above the point where it emerges from behind the upper jejunal mesentery, leaving a slightly longer stump of colon on the right of this mesentery, which was readily anastomosed end-to-end with the terminal ileum. Measurements made in the mature animals indicated that about $75 \%$ of the gut between the anus and the terminal ileum was removed by this more limited operation, and about 85 to $90 \%$ by the operation done in the first two pigs.

When the animals were killed, the chest and abdomen were opened in the midline and the state of the peritoneal cavity and of the intestinal tract within it carefully inspected. The whole of the stomach and guts were then removed en bloc, the intestinal tract was dissected and, after noting any adhesions, was laid out at full length on a bench. The intestines were measured and the most appropriate portions removed for histology. Corresponding lengths were removed from the intestines of normal animals of similar age and size. No abnormalities were found in any of the organs outside the peritoneal cavity.

The faeces analysed for Tables II and III were mixed samples, collected by hand immediately they were passed and after the animals had been on the respective diets for 3 or 4 days.

After the carcasses had been hung for 24 hours at $4{ }^{\circ} \mathrm{C}$ they were measured by the technique described by the National Pig Progeny Testing Board (1959) and Lister and McCance (1967), and the figures given in Table IV are the mean values for the two sides of the body. The analytical methods were the same as those used by McCance, Rutishauser, and Boozer (1970).

\section{Results}

The results of the two metabolism experiments performed on the boy are shown in Table I. The intakes and excretions of $\mathrm{N}, \mathrm{Na}, \mathrm{K}, \mathrm{Ca}, \mathrm{P}$, and fat were measured on both occasions, but those of $\mathrm{Cl}$ only in 1963 and those of $\mathrm{Mg}$ only in 1971. The boy was in good positive balance within days of his first operation in spite of losing, in his faeces, rather more of his intake of $\mathrm{Na}, \mathrm{K}$, and $\mathrm{Ca}$ than a normal boy. He must have remained in good positive balance subsequently, moreover, to have made such good growth, but he was only in trifling positive balance for $\mathrm{N}$ and $\mathrm{Na}$ and in negative balance for $\mathrm{Ca}$ and $\mathrm{P}$ when the intakes and excre-

TABLE I

Daily intakes, outputs, and other measurements on patient

\begin{tabular}{|c|c|c|c|c|c|c|c|}
\hline \multirow{2}{*}{ Material } & \multirow{2}{*}{ Intake } & \multicolumn{3}{|c|}{ Output } & \multirow{2}{*}{ Balance } & \multirow{2}{*}{$\begin{array}{l}\text { Absorption } \\
\text { (\% of intake) }\end{array}$} & \multirow{2}{*}{$\begin{array}{c}\text { Retention } \\
\text { (\% of intake) }\end{array}$} \\
\hline & & Urine & Faeces & Total & & & \\
\hline $\begin{array}{l}\text { Aged } 14 \text { days } \\
\mathrm{N}(\mathrm{g}) \\
\mathrm{Na}(\mathrm{mEq}) \\
\mathrm{Cl}(\mathrm{mEq}) \\
\mathrm{K} \text { (mEq) } \\
\mathrm{Ca}(\mathrm{mEq}) \\
\mathrm{P} \text { (mmol) } \\
\text { Fat (g) }\end{array}$ & $\begin{array}{c}1 \cdot 29 \\
5 \cdot 72 \\
10 \cdot 9 \\
8 \cdot 29 \\
6 \cdot 8 \\
2 \cdot 29 \\
16 \cdot 7\end{array}$ & $\begin{array}{l}0 \cdot 15 \\
0 \cdot 187 \\
1 \cdot 55 \\
0 \cdot 90 \\
0 \cdot 025 \\
0 \cdot 05 \\
0 \cdot 0\end{array}$ & $\begin{array}{l}0 \cdot 18 \\
0 \cdot 741 \\
1 \cdot 85 \\
1 \cdot 04 \\
3 \cdot 75 \\
0 \cdot 13 \\
1 \cdot 0\end{array}$ & $\begin{array}{l}0 \cdot 33 \\
0 \cdot 93 \\
3 \cdot 40 \\
1 \cdot 94 \\
3 \cdot 80 \\
0 \cdot 18 \\
1 \cdot 0\end{array}$ & $\begin{array}{l}+0.96 \\
+4 \cdot 79 \\
+7 \cdot 50 \\
+6.35 \\
+3 \cdot 0 \\
+2 \cdot 11 \\
+15 \cdot 7\end{array}$ & $\begin{array}{l}86 \\
87 \\
83 \\
87 \\
45 \\
94 \\
94\end{array}$ & $\begin{array}{l}74 \\
85 \\
69 \\
77 \\
44 \\
92 \\
94\end{array}$ \\
\hline $\begin{array}{l}\text { Aged } 9 \text { yr } 7 \text { mrh } \\
\mathrm{N} \text { (g) } \\
\mathrm{Na}(\mathrm{mEq}) \\
\mathrm{K} \text { (mEq) } \\
\mathrm{Ca}(\mathrm{mEq}) \\
\mathrm{Mg}(\mathrm{mEq}) \\
\mathrm{P} \text { (mmole) } \\
\text { Fat (g) }\end{array}$ & $\begin{array}{l}5 \cdot 31 \\
88 \cdot 5 \\
40 \cdot 2 \\
18 \cdot 9 \\
10 \cdot 3 \\
18 \cdot 4 \\
33 \cdot 8\end{array}$ & $\begin{array}{c}4 \cdot 70 \\
72 \cdot 5 \\
38 \cdot 1 \\
1 \cdot 70 \\
5 \cdot 00 \\
13 \cdot 6 \\
-\end{array}$ & $\begin{array}{c}0 \cdot 40 \\
0 \cdot 89 \\
2 \cdot 13 \\
21 \cdot 3 \\
5 \cdot 30 \\
5 \cdot 50 \\
1 \cdot 76\end{array}$ & $\begin{array}{c}5 \cdot 10 \\
74 \cdot 4 \\
40 \cdot 23 \\
23 \cdot 0 \\
10 \cdot 30 \\
19 \cdot 1 \\
1 \cdot 76\end{array}$ & $\begin{array}{l}+0.21 \\
+14 \cdot 1 \\
\pm 0.0 \\
=4 \cdot 1 \\
\pm 0.0 \\
=0.7 \\
+32 \cdot 0\end{array}$ & $\begin{array}{c}93 \\
99 \cdot 1 \\
95 \\
-13 \\
51 \\
70 \\
95\end{array}$ & $\begin{array}{c}4 \\
16 \\
0 \\
-22 \\
0 \\
-3 \cdot 9 \\
95\end{array}$ \\
\hline
\end{tabular}


tions were measured again in 1971. His absorption, however, including that of water was excellent, and the reason why he was not in a more satisfactory state of balance was probably because the intakes arranged and measured for him were so small. The intake arranged for him was only $2040 \mathrm{kcal} /$ day. He took some toast at least once outside his allowance which is understandable since the recommended energy intake for boys of his age is nearly $2500 \mathrm{kcal}$, and some naturally exceed this. The intake of $\mathrm{Ca}$ allowed for him was also very small for a boy of his age, and the negative balance may have been increased as the result of confinement and inactivity in the ward.

The 11 piglets passed very loose stools for some time after the operation. 4 of them died within 4 days from dehydration or some defect in the anastomosis, and 2 more within 8 days. The remaining 5, all females, lived to maturity, and their stools gradually became less and less watery as they grew older until, in the end, they were almost normal (see later). One of them, 1Z1, which had never conceived, died suddenly during a Saturday night at the age of 29 months and it was only possible to carry out a rather limited necropsy. The animal was extremely fat and had appeared perfectly normal the day before. Massive adhesions and a tangle of guts were found about $4 \mathrm{~m}$ from the ileocolic suture. Proximal to this the whole of the small intestine was extremely dilated, of a dark purple colour, and full of offensive brown granular material, liquid, and gas. The mesentery appeared to be highly engorged but, distal to the obstruction, the lower part of the ileum and rectum were normal. There were a good many calcified foci among the fibrous adhesions.
Two of the gilts that had had their large intestines removed had litters. $8 \mathrm{M} 6$ gave birth to 10 piglets of which 4 were born dead, 1 died, 1 was overlain, and the remaining 4 were suckled successfully. 1Z3's litter contained only 5 piglets of which 4 were large and were suckled without any trouble: the fifth died.

Of the remaining $2,8 \mathrm{Ml}$ would never stand for the boar and was not artificially inseminated, and 2U3 developed lesions of the joints in the back legs which were thought to be subacute swine erysipelas. These did not prevent her eating and growing normally but she was never served.

Fig. 1 shows the average growth rate of 9 normal pigs and of the 5 pigs that had had their large intestine removed. Two of the normal pigs were litter mates and fed on exactly the same diets as

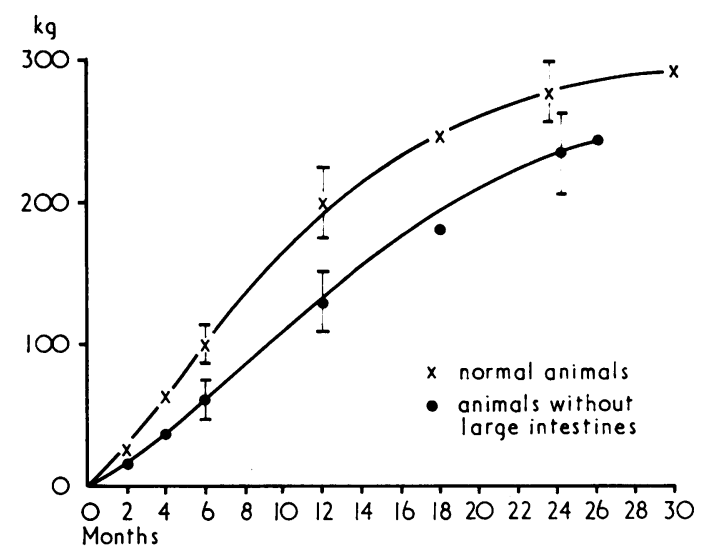

Fig. 1.-Mean rates of growth of normal pigs and of pigs without a large intestine.

TABLE II

Effect of removing large intestine of pigs soon after birth on composition of faeces in adult life (mean and SD)

\begin{tabular}{|c|c|c|c|c|c|}
\hline & \multirow{2}{*}{$\begin{array}{l}\text { Water } \\
\text { (g/100 g } \\
\text { wet wt) }\end{array}$} & \multicolumn{4}{|c|}{ Calculated (g/100 g dry matter) } \\
\hline & & Water & Nitrogen & Fat & $\begin{array}{l}\text { Undetermined } \\
\text { matter } \\
\text { (by difference) }\end{array}$ \\
\hline \multirow[t]{3}{*}{$\begin{array}{l}5 \text { normal animals } \\
5 \text { experimental animals }\end{array}$} & $\begin{array}{r}75 \cdot 3 \\
\pm 3 \cdot 7 \\
82 \cdot 6 \\
\pm 3 \cdot 4\end{array}$ & $\begin{array}{l}312 \\
\pm 57 \cdot 6 \\
523 \\
\pm 186\end{array}$ & $\begin{array}{r}2 \cdot 21 \\
\pm 0 \cdot 49 \\
2 \cdot 48 \\
\pm 0 \cdot 13\end{array}$ & $\begin{array}{r}4 \cdot 6 \\
\pm 0 \cdot 8 \\
5 \cdot 2 \\
\pm 1 \cdot 3\end{array}$ & $\begin{array}{l}70 \cdot 3 \\
\pm 1 \cdot 51 \\
66 \cdot 8 \\
\pm 2 \cdot 81\end{array}$ \\
\hline & \multicolumn{5}{|c|}{ Calculated per $100 \mathrm{~g}$ dry matter } \\
\hline & $\mathrm{Na}(\mathrm{mEq})$ & $\mathrm{K}(\mathrm{mEq})$ & $\mathrm{Ca}$ (mg) & $\mathbf{M g}(\mathbf{m g})$ & $\mathrm{P}$ as $\mathrm{Po}_{4}(\mathrm{mg})$ \\
\hline $\begin{array}{l}5 \text { normal animals } \\
5 \text { experimental animals }\end{array}$ & $\begin{array}{r}65 \cdot 2 \\
\pm 22 \cdot 7 \\
88 \cdot 1 \\
\pm 21 \cdot 6\end{array}$ & $\begin{array}{r}48 \cdot 9 \\
\pm 25 \cdot 4 \\
72 \cdot 9 \\
\pm 21 \cdot 7\end{array}$ & $\begin{array}{l}1085 \\
\pm 213 \\
1083 \\
\pm 191\end{array}$ & $\begin{array}{r}740 \\
\pm 286 \\
621 \\
\pm 145\end{array}$ & $\begin{array}{r}2293 \\
\pm 590 \\
2226 \\
\pm 656\end{array}$ \\
\hline
\end{tabular}


TABLE III

Effect on composition of faeces of adding fat for several days to diets of 2 pigs without large intestine

\begin{tabular}{|c|c|c|c|c|c|c|}
\hline & \multirow{2}{*}{$\begin{array}{l}\text { Water } \\
\text { (g/100 g } \\
\text { wet wt) }\end{array}$} & \multicolumn{5}{|c|}{ Calculated ( $\mathrm{g} / 100 \mathrm{~g}$ dry matter) } \\
\hline & & Water & Nitrogen & Fat & Minerals & $\begin{array}{l}\text { Undetermined } \\
\text { matter } \\
\text { (by difference) }\end{array}$ \\
\hline $\begin{array}{l}\text { (1) Basal diet alone } \\
\text { Basal diet } 87.5 \%\end{array}$ & $78 \cdot 8$ & 371 & $2 \cdot 36$ & $4 \cdot 92$ & $14 \cdot 10$ & $60 \cdot 4$ \\
\hline & $77 \cdot 0$ & 335 & $2 \cdot 49$ & $12 \cdot 5$ & $6 \cdot 30$ & $65 \cdot 7$ \\
\hline Fat $\quad 20 \%$ & $76 \cdot 6$ & 328 & $2 \cdot 85$ & $7 \cdot 5$ & $6 \cdot 27$ & $68 \cdot 5$ \\
\hline $\begin{array}{l}\text { (2) Basal diet alone } \\
\text { Basal diet } 87.5 \%\end{array}$ & $82 \cdot 9$ & 413 & $1 \cdot 90$ & $7 \cdot 37$ & $11 \cdot 30$ & $71 \cdot 3$ \\
\hline $\begin{array}{c}\text { Fat } 12 \cdot 5 \% \\
\text { Basal diet } 80 \%\end{array}$ & $81 \cdot 0$ & 426 & $2 \cdot 48$ & $8 \cdot 73$ & $4 \cdot 86$ & $75 \cdot 8$ \\
\hline Fat $\quad 20 \%$ & $80 \cdot 2$ & 405 & $2 \cdot 34$ & $6 \cdot 27$ & $5 \cdot 3$ & $70 \cdot 5$ \\
\hline
\end{tabular}

the experimental ones throughout life, but their curves were close to the average ones for the normal animals and the general average for 9 has been given. The experimental pigs grew more slowly at first and they did not show the same inflection in the growth curve from 2 to 6 months that the normal pigs did. In their second year, however, they grew more quickly and showed a considerable capacity to catch up.

The differences between the means were highly significant at 6 months and 1 year. The difference was smaller at 2 years than it had been at 1 , but it was still significant $(T=2 \cdot 9, P<0 \cdot 01)$.

Table II shows the effect of removing the colon and caecum on the composition of the faeces. There was significantly more water in the faeces of the colectomized animals $(P<0.05)$ but none of the other differences was significant when expressed per $100 \mathrm{~g}$ solid matter. The 'undetermined' material, mostly straw, lignins, and unavail- able carbohydrates, was taken to be the difference between 100 and the $N \times 6 \cdot 25$, the fat and the minerals all expressed as $\mathrm{g}$.

Table III shows the effect of adding fat to the diets of 2 of the adult colectomized pigs. When the diets contained $20 \%$ fat, the animals were getting about $34 \%$ of their calories from this source. Though adding $12.5 \%$ fat to its diet raised the amount of fat the first pig was excreting, the figures obtained from the 2 animals, taken together and as a whole, indicate that the digestion and absorption of fat were not being interfered with to any extent by the time the animals had reached maturity.

Table IV shows the carcass measurements made on the 4 experimental animals killed by arrangement, and those made on healthy normal animals of the same sex. The animals reared after their large intestine had been removed were all lighter than the controls and one of the latter was an unusually

TABLE IV

Carcass measurements of mature female pigs reared without large intestines and of their controls

\begin{tabular}{|c|c|c|c|c|c|c|c|c|c|c|}
\hline \multirow{2}{*}{ No. } & \multicolumn{2}{|c|}{ Weight (kg) } & \multicolumn{4}{|c|}{ Lengths (cm) } & \multirow{2}{*}{$\begin{array}{l}\text { Depth } \\
\text { of side } \\
\text { (cm) }\end{array}$} & \multicolumn{3}{|c|}{ Back fat thickness $(\mathrm{cm})$} \\
\hline & Alive & $\begin{array}{c}\text { Eviscera- } \\
\text { ted }\end{array}$ & $\underset{\text { leg }}{\text { Hind }}$ & Loin & Side & $\begin{array}{l}\text { Toe to } \\
\text { snout }\end{array}$ & & Loin & $\begin{array}{l}\text { Mid- } \\
\text { back }\end{array}$ & Shoulder \\
\hline $\begin{array}{l}\text { Experimental } \\
1 \mathrm{Z3} \\
2 \mathrm{U} 3 \\
8 \mathrm{M} 1 \\
8 \mathrm{M} 6 \\
\text { Mean }\end{array}$ & $\begin{array}{l}275 \\
263 \\
236 \\
236 \\
253\end{array}$ & $\begin{array}{l}220 \\
221 \\
191 \\
188 \\
205\end{array}$ & $\begin{array}{l}78 \cdot 0 \\
78 \cdot 0 \\
70 \cdot 5 \\
72 \cdot 5 \\
74 \cdot 8\end{array}$ & $\begin{array}{l}48 \cdot 0 \\
49 \cdot 0 \\
47 \cdot 0 \\
48 \cdot 0 \\
48 \cdot 0\end{array}$ & $\begin{array}{r}100 \cdot 0 \\
106 \cdot 0 \\
95 \cdot 0 \\
98 \cdot 5 \\
100 \cdot 0\end{array}$ & $\begin{array}{l}239 \cdot 0 \\
250 \cdot 0 \\
227 \cdot 0 \\
232 \cdot 0 \\
237 \cdot 0\end{array}$ & $\begin{array}{l}54 \cdot 0 \\
52 \cdot 0 \\
52 \cdot 0 \\
49 \cdot 5 \\
52 \cdot 0\end{array}$ & $\begin{array}{l}7 \cdot 0 \\
7 \cdot 0 \\
5 \cdot 8 \\
4 \cdot 8 \\
6 \cdot 2\end{array}$ & $\begin{array}{l}5 \cdot 0 \\
6 \cdot 0 \\
5 \cdot 5 \\
5 \cdot 3 \\
5 \cdot 5\end{array}$ & $\begin{array}{l}8 \cdot 0 \\
8 \cdot 5 \\
8 \cdot 5 \\
8 \cdot 0 \\
8 \cdot 3\end{array}$ \\
\hline $\begin{array}{c}\text { Controls } \\
1 Z 8 \\
1 Z 9 \\
1 S 1 \\
4 R 1 \\
\text { Mean }\end{array}$ & $\begin{array}{l}320 \\
268 \\
310 \\
302 \\
300\end{array}$ & $\begin{array}{l}273 \\
217 \\
262 \\
252 \\
250\end{array}$ & $\begin{array}{l}79 \cdot 0 \\
76 \cdot 0 \\
80 \cdot 0 \\
79 \cdot 0 \\
78 \cdot 5\end{array}$ & $\begin{array}{l}52 \cdot 0 \\
52 \cdot 0 \\
52 \cdot 0 \\
50 \cdot 0 \\
51 \cdot 5\end{array}$ & $\begin{array}{l}110 \cdot 0 \\
109 \cdot 0 \\
111 \cdot 0 \\
112 \cdot 0 \\
110 \cdot 5\end{array}$ & $\begin{array}{l}259 \cdot 0 \\
247 \cdot 0 \\
259 \cdot 0 \\
256 \cdot 0 \\
255 \cdot 0\end{array}$ & $\begin{array}{l}58 \cdot 0 \\
53 \cdot 0 \\
56 \cdot 0 \\
56 \cdot 5 \\
56 \cdot 0\end{array}$ & $\begin{array}{l}6 \cdot 0 \\
5 \cdot 5 \\
7 \cdot 3 \\
7 \cdot 0 \\
6 \cdot 5\end{array}$ & $\begin{array}{l}5 \cdot 0 \\
6 \cdot 0 \\
6 \cdot 0 \\
6 \cdot 0 \\
5 \cdot 8\end{array}$ & $\begin{array}{l}9 \cdot 0 \\
8 \cdot 0 \\
8 \cdot 5 \\
9 \cdot 0 \\
8 \cdot 6\end{array}$ \\
\hline
\end{tabular}




\section{Clinical and experimental results of removing the large intestine soon after birth}

small sow. The linear dimensions were also smaller on the whole but there was considerable overlapping in the fat measurements, and little to choose between the groups in this respect.

\section{Discussion}

The present results suggest that removal of the terminal ileum, the ileocaecal valve, the caecum, and practically the whole of the colon in the neonatal period should be well tolerated and that subsequently bowel function should be satisfactory though full genetic stature may not be achieved.

This work has, however, raised 3 points which require some discussion.

(1) It has been a subject for debate for a long time whether removal of one part of the intestinal tract is followed by hypertrophy of the remainder. Flint (1912) found considerable hypertrophy and has often been quoted for this, and so did Clatworthy, Saleeby, and Lovingwood (1952), Clayton and Cotton (1961), and Rickham (1967). Trzebicky (1894), Evans and Brenizer (1907), and Jensenius (1945) found none, Wildegans (1925) none except just above the anastomoses, and Monari (1896) microscopical hypertrophy only.

The weakness of all the earlier and much of the more recent work has been that no one author has carried out the same operation enough times on his chosen species to find out clearly what the results of that particular operation on that particular species were. Booth et al. (1959), however, using adult rats, found that removal of the lower half of the small intestine led to rapid transit times and was not followed by hypertrophy of the jejunum, whereas removal of the jejunum led to more normal transit times and hypertrophy of the ileum.
That the removal of the jejunum was less traumatic than that of the ileum had perhaps been foreshadowed to some extent by the results of Stassof (1914), Jensenius (1945), and Kremen, Linner, and Nelson (1954). McCance and Wilkinson (1967) removed the lower half of the small intestine from 16 pigs soon after birth. The progress of these pigs tended to be interfered with by crippling adhesions, but two became sexually mature adults and one had several litters. No anatomical evidence of hypertrophy of the jejunum was found apart from that which might have been expected locally from the adhesions. These results, taken with those of Booth et al. (1959), indicate that hypertrophy should not be expected proximal to the part excised, but Wilmore et al. (1971), working on the effects of intravenous feeding after extensive resections in puppies 10 weeks old, found a complicated picture of hypertrophy both above and below the part excised. In the present experiments no macroscopical or microscopical evidence of hypertrophy of the small intestine or of the rectum was found in any of the animals, and Fig. 2 shows sections from corresponding portions of the ileum of a normal and an experimental adult pig.

(2) It is well known that resections of portions of the intestinal tract are followed by a more or less prolonged period of diarrhoea which ultimately subsides if too much bowel has not been removed. Reasons currently advanced for this in terms of 'adaptation' of the gut are not very satisfactory, and to treat the diarrhoea surgically by reversing segments of the intestine to promote some antiperistalsis (Stahlgren et al., 1962; Baldwin-Price, Copp, and Singleton, 1965) seems still less so. A more physiological explanation appears to be the

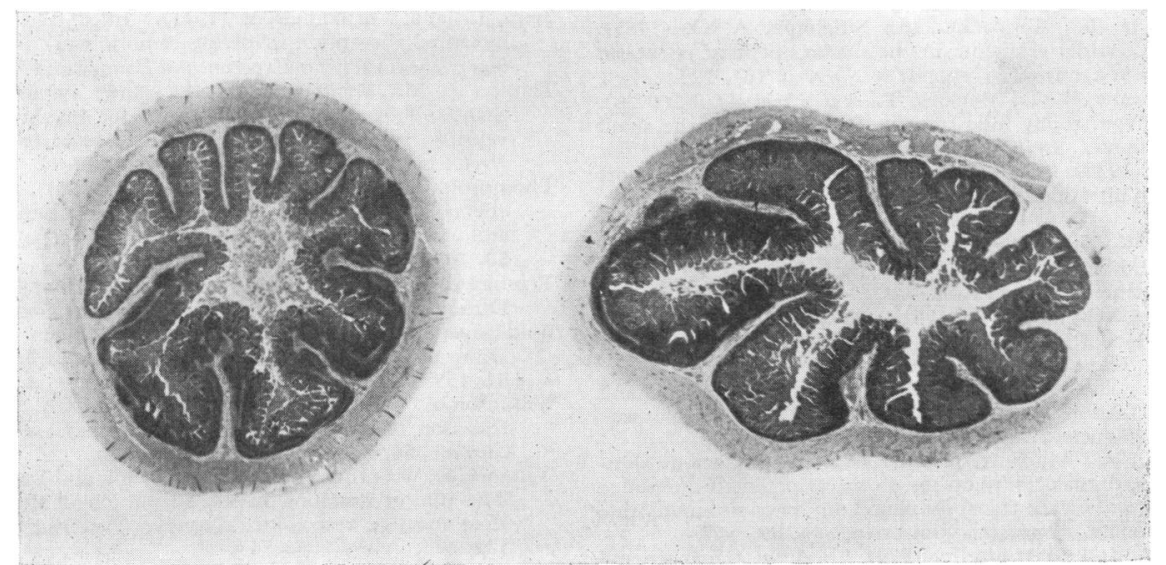

FIG. 2.-Sections, subjected to identical treatment and magnification, across the same part of the ileum of 2U3, a colectomized pig (left), and a normal pig about the same weight, $1 Z 8$ (right). 
following. The diarrhoea is primarily caused by the shortened intestinal tract not absorbing enough sodium. The diarrhoea can be accentuated if large amounts of sodium chloride are given by mouth with the idea of replacing the loss, and the patient's life saved by reducing the intake of sodium chloride (Kerpel-Fronius, Miltényi, and Görgényi, 1970). The initial diarrhoea, moreover, which seems to follow all resections must reduce the volume of the extracellular fluids and bring in the renin/angiotensin/aldosterone mechanisms, and the angiotensin/aldosterone system is now known from both direct and indirect evidence to promote the reabsorption of sodium not only from the renal tubules, but also from the gut (Stein and Wertheimer, 1941; Crocker and Munday, 1967; Edmonds and Marriott, 1967, 1970; Thompson and Edmonds, 1971; Munday, Parsons, and Shaikh, 1969; Mailman and Ingraham, 1971). This in itself may put an end to the diarrhoea without invoking any delaying action on the part of the muscles or valves of the intestinal tract. It would not be expected to lead to many, if any, visible signs of hypertrophy.

(3) Much of the functional improvement of the gastrointestinal tract has been attributed to the ileocaecal valve, but there is really no solid experimental evidence to support this point of view. The present work does not, and, furthermore, it raises the whole question of what is the function of the valve. The problem is under investigation.

The authors are indebted to the ward staff and theatre staff for their part in this work: also to the laboratory staffs in London and Cambridge, and to Terry Cowen who nursed the animals when they were sick, bred them, fed them, and looked after them all their lives.

\section{REFERENCES}

Baldwin-Price, H. K., Copp, D., and Singleton, A. O. (1965) Reversed intestinal segments in the management of anenteric malabsorption syndrome. Annals of Surgery, 161, 225.

Booth, C. C., Evans, K. T., Menzies, T., and Street, D. F. (1959). Intestinal hypertrophy following partial resection of the small bowel in the rat. British fournal of Surgery, 46, 403.

Brown, M. R. (1938). Deficiency syndromes secondary to short circuit small intestine. (Abst.). fournal of Clinical Investigation, $17,529$.

Clatworthy, H. W., Saleeby, R., and Lovingood, C. (1952). Extensive small bowel resection in young dogs: its effect on growth and development. Surgery, 32, 341.

Clayton, B. E., and Cotton, D. A. (1961). A study of malabsorption after resection of the entire jejunum and the proximal half of the ileum. Gut, $2,18$.

Crocker, A. D., and Munday, K. A. (1967). Aldosterone and angiotensin action on water absorption in the rat jejunum. Fournal of Physiology, 192, 36P.

Edmonds, C. J., and Marriott, J. C. (1967). The effect of aldosterone and adrenalectomy on the electrical potential difference of rat colon and on the transport of sodium, potassium, chloride and bicarbonate. Fournal of Endocrinology, 39, 517.

Edmonds, C. J., and Marriott, J. (1970). Sodium transport and short-circuit current in rat colon in vivo and the effect of aldosterone. Fournal of Physiology, 210, 1021.

Evans, H. M., and Brenizer, A. G. (1907). Notes on the resection of large portions of the small intestine. Fohns Hopkins Hospital Bulletin, 18, 477.

Flint, J. M. (1912). The effect of extensive resections of the small intestine. Fohns Hopkins Hospital Bulletin, 23, 127.

Hey, E. N., Ellis, M. I., and Walker, W. (1972). Ileocolitis after exchange transfusion. Lancet, 1, 266.

Jensenius, H. C. (1945). Results of Experimental Resections of the Small Intestine on Dogs: Experimental Enteroprival Sprue. Lewis, London.

Kerpel-Fronius, E., Miltényi, M., and Görgényi, A. (1970). Osmotic diarrhoea due to high sodium chloride intake following subtotal resection to the small intestine. Digestion (Basel), 3, 20.

Kremen, A. J., Linner, J. H., and Nelson, C. H. (1954). An experimental evaluation of the nutritional importance of proximal and distal small intestine. Annals of Surgery, 140, 439.

Lister, D., and McCance, R. A. (1967). Severe undernutrition in growing and adult animals. 17. The ultimate results of rehabilitation: pigs. British fournal of Nutrition, 21, 787.

McCance, R. A., Rutishauser, I. H. E., and Boozer, C. N. (1970). Effect of kwashiorkor on absorption and excretion of $\mathrm{N}$, fat, and minerals. Archives of Disease in Childhood, 45, 410.

McCance, R. A., and Wilkinson, A. W. (1967). Experimental resection of the intestine in newborn pigs. British fournal of Nutrition, 21, 731.

McCandless, A. E. (1971). Ileocolitis following exchange transfusion. Lancet, 2, 762 .

McCandless, A. E. (1972). Ileocolitis after exchange transfusions. Lancet, 1, 266.

Mailman, D. S., and Ingraham, R. C. (1971). Effects of hemorrhage and tilting on $\mathrm{Na}, \mathrm{Cl}$ and $\mathrm{H}_{2} \mathrm{O}$ absorption from the intestine. Proceedings of the Society for Experimental Biology and Medicine, 137, 78.

Monari, U. (1896). Experimentelle Untersuchungen über die Abtragung des Magens und des Dünndarms beim Hunde. Beiträge zur klinischen Chirurgie, 16, 479.

Munday, K. A., Parsons, B. J., and Shaikh, D. M. (1969). The control of colon fluid transport by aldosterone and angiotensin. See Fournal of Physiology (1970), 206, 39P-40P.

National Pig Progeny Testing Board (1959). Annual Report, 1959. Interpretation of Boar Test Reports, 2, 17.

Rickham, P. P. (1967). Massive small intestinal resection in newborn infants. Annals of the Royal College of Surgeons of England, 41, 480.

Stahlgren, L. H., Umana, G., Roy, R., and Donelly, J. (1962). A study of intestinal absorption in dogs following massive small intestinal resection and insertion of an antiperistaltic segment. Annals of Surgery, 156, 483.

Stassof, B. (1914). Experimentelle Untersuchungen über die kompensatorischen Vorgange bei Darmresektion. Beiträge zur klinischen Chirurgie, 89, 527.

Stein, L., and Wertheimer, E. (1941). Effect of adrenalectomy on intestinal absorption involving osmotic work in rats. Proceedings of the Society for Experimental Biology and Medicine, 46, 172.

Tanner, J. M., Whitehouse, R. H., and Takaishi, M. (1966). Standards from birth to maturity for height, weight, height velocity, and weight velocity: British children, 1965. Part 2. Archives of Disease in Childhood, 41, 613.

Thompson, B. D., and Edmonds, C. J. (1971). Comparison of effects of prolonged aldosterone administration on rat colon and renal electrolyte excretion. Fournal of Endocrinology, $50,163$.

Trzebicky, R. (1894). Ueber die Grenzen der Zulässigkeit der Dünndarmresection. Archiv für klinische Chirurgie, 48, 54.

Wildegans, H. (1925). Stoffwechselstörungen nach grossen Dünndarmresektionen. Deutsche medizinische Wochenschrift, 51, 1558.

Wilkinson, A. W., Hughes, E. A., and Toms, D. A. (1963). Massive resection of the small intestine in infancy. British fournal of Surgery, 50, 715

Wilmore, D. W., Dudrick, S. J., Daly, J. M., and Vars, H. M. (1971). The rôle of nutrition in the adaptation of the small intestine after massive resection. Surgery, Gynecology and Obstetrics, 132, 673.

Correspondence to Professor R. A. McCance, 4 Kent House, Sussex Street, Cambridge CB1 1PH. 